societies. Whether as a result of the Conference of Delegates at the British Association, or the various criticisms and suggestions appearing in NATURE and other journals, those responsible for the production of publications of local interest are certainly adding considerably to the value of these transactions by confining the contents as near as possible to the district covered by the societies' activities.

Some societies are sufficiently strong financially, and in scientific workers, to continue printing their publications independently; others, wisely, have amalgamated, and by thorough organisation have produced a joint publication containing the reports of the various committees and sections, which is of permanent value. As an example of the former, we have recently received the Proceedings and Transactions of the Croydon Natural History and Scientific Society (Vol. 9, Part 4. Price 5s. net). This covers the period February I923 to January I925. It includes reprints of the various monthly circulars which the Society has issued containing particulars of the meetings and excursions, with summaries of the work of the sections of archæology, botany, geology, microscopy, physics and chemistry, regional survey, and sociology and psychology. There are the two presidential addresses of Mr. G. M. Davies, one dealing with geology and lines of transport in the Croydon district, and the other with the sea in Surrey, both being of particular value to Croydon naturalists.

An exceedingly valuable part of the publication is that devoted to the meteorological reports for 1923 and I924, by Mr. F. Campbell Bayard. The cost of compiling and printing these, both from the point of view of time and money, must have been tremendous, and we are not surprised to learn from the Council's report that for both reasons the printing of these reports will not be continued, though full particulars will be sent to the British Rainfall Organisation. Mr. Campbell Bayard is to be congratulated on having accomplished this onerous work for thirty-seven years, and the Society has done well to elect him an honorary member. As a frontispiece to the volume is a really beautiful protrait of the late Mr. William Whitaker, who was one of the most familiar figures at the meetings of many scientific societies, and took a prominent part in Croydon affairs.
The South-Eastern Naturalist comes under the second category, and this Society and its organisation is founded upon that of the Yorkshire Naturalists' Union, the pioneer scientific union in the British Islands. The South-Eastern Union's publication, the South-Eastern Naturalist for 1925 (1xxxii + ro7 pp. Price 5s. net), contains a record of the Folkestone congress. As frontispiece is the inevitable "group," which always impresses us as containing portraits of a greater proportion of old people than can be found in any other group of this character! Here the reports and proceedings of the various sections and committees, records of the congress, the obituary notices, etc., are thoroughly well done. The presidential address of Sir John Russell, entitled "The Place of Science in Rural Life," is printed. E. C. Stuart Baker refers to evolution and field naturalists ; A. Steven Corbet writes on the marshwarbler in Britain, with a bibliography; D. Ward Cutler describes life in a garden soil ; Prof. A. G. Tansley writes on vegetation of the southern English Chalk; Miss Lillian Lyle on seaweeds of Folkestone-how they grow; A. L. Leach on geological elements in the scenery of south-eastern England (with many interesting illustrations); C. J. Gilbert on the genesis of the Straits of Dover and the creation of Romney Marsh; G. L. Pepler on regional survey as a preliminary to town planning; E. A. Robins and J. H. Pledge on making photographic prints for regional survey; E. A. Martin on problems in anthropology; A. H. Reade on Barfrestone Church; and A. G. Davies on notes on new geological sections in the London district.

In his paper on problems in anthropology, $\mathrm{Mr}$. Martin says: "When we find what looks like an implement and we do not quite know what were its uses, we say it was some kind of scraper. Scrapers were of all ages in human times. Eoliths would make good scrapers. Has any one ever seen a dog or cat take a stone to scrape himself with it? Here again is evidence of the growth of self-consciousness, when man wished to lead a cleanly life. I take it that he did not use his scrapers only for cleaning the skins of animals he had captured and which he wished to utilise as clothing. He would use them to clean himself," and so on.

T. S.

\title{
Annual Meeting of the Science Masters' Association.
}

THE twenty-sixth annual meeting of the Science Masters' Association was held on January 5, 6, and 7 at the Household and Social Science Department of King's College for Women, by kind permission of the authorities. There was a large attendance, and the meeting was in every way very successful. After the opening dinner in the refectory of the College, the presidential address was delivered by the Bishop of Birmingham, the Right Rev. Dr. C. W. Barnes.

Dr. Barnes directed attention to the effect of the progress of science upon religious belief, and said that science is now, and must continue to be, an essential element in human culture. It not only gives us a picture of the universe, in which all man's spiritual faculties must find a place, but also helps us the better to understand ourselves and our fellow men. It will, in due course, enable mankind to strengthen its social fabric, to which end it is desirable to check the multiplication of degenerate racial stock. The principles of science and scientific method must be applied universally, even to the phenomena of the religious consciousness. True religion will not suffer if the scientific temper prevails. The absurd contention that if man were a developed ape there could be nothing in him but what the ape possessed is almost forgotten. Using Lloyd Morgan's phrase, Dr. Barnes pointed out that evolution is characterised by the " emergence" of new degrees of reality. Science, he said, can help human progress by destroying false realisations of religious experience and can purify religion by divesting it of accretions which linger from pre-scientific times. It has already banished fear from the minds of educated men by giving them a satisfactory understanding of natural phenomena. It has also banished the gods; the universe is a unity and not subject to the control of super-personalities. Science is built on the postulate of the uniformity of Nature, and its triumphs show that this postulate is sound.

Science has banished the gods: has it banished God? Dr. Barnes is of opinion that, in effect, it has done this if pantheism or naturaiism are the interpretation of the universe to which it leads; but no such interpretation is necessary or even probable. That the universe is a self-acting machine is an incredible

No. 2933, vol. I I 7] 
assumption, and renders the emergence of man's spiritual faculties entirely inexplicable. If, on the other hand, we identify God with the universe, good and evil are alike divine, our moral intuitions are meaningless. Goodness, beauty, and truth must of necessity find a place in our interpretation of the universe, so naturalism and pantheism do not adequately explain the cosmos to which man belongs. Science, then, does not banish God, neither does it banish the conception of the kingdom of God as formulated by the Founder of Christianity. Science, however, can answer none of the ultimate questions. They are not her province. But though her range is limited, within that range she leads us from error to truth, from fantasy to fact. On the truth which science has revealed and is still revealing we have built the new humanism of this age. The religious outlook, in which modern science has been cradled, will not only be able to co-exist with the new humanism, but will derive from it an added power of appeal to the intellect of man.

A vote of thanks to the president was ably moved by a very old and valued friend of the Association, Prof. A. Smithells, and was seconded in a felicitous speech by Prof. Percy Nunn; it was carried with acclamation.

Thursday's programme included a lecture by Prof. Leonard Hill upon " Sunshine, Open Air, and Health," and a discussion upon laboratory assistants, laboratory management, and school exhibitions. On the question of laboratory assistants in schools, a matter which affects most members of the Association very closely, it is felt that some definite scheme for the provision, training, and payment of such men is urgently required, and the committee was requested to make a special inquiry into the subject.

At the business meeting, the momentous decision was taken to institute the formation of local branches. The reasons which led the Association to undertake this step were chiefly two: $(a)$ to get into closer contact with local universities, in order to deal more easily with the numerous problems which arise in the teaching of science in schools and in the correlation of school courses with university requirements, etc.; and (b) to promote the social side of the Association. Arguments against the formation of branches were put forward, but the weight of the meeting was strongly in favour of the idea. We are pleased to note that, according to the rules drafted for the regulation of branches, non-members who are interested in the objects of the Association may, at the discretion of any branch committee, be invited as guests to meetings of the branch other than a business meeting. This affords opportunity for closer co-operation between the Science Masters' Association and the Association of Women Science Teachers, which, in view of the fact that both associations have the same aims and are faced by the same, or very similar, problems, seems very desirable.

Additional features of the meeting were lectures and demonstrations by Prof. B. J. Collingwood, Dr. C. S. Myers, Rev. F. Aveling, Miss W. Spielman and others, while visits were arranged to the National Physical Laboratory and the General Electric Company's Laboratories. There was also an excellent exhibition of scientific apparatus, and of chemicals, by the leading manufacturing firms, while the publishers' show in the Library was a source of great interest, judging from the crowds of members always present there. The table reserved for books written by members of the Association was striking testimony to the literary activity of science masters, and the members' exhibits of apparatus bore witness to no little ingenuity. It is not too much to say that, of all the numerous associations of teachers in Great Britain, the Science Masters' Association is one of the keenest and most vigorous.

The meeting in January 1927 is to be held at Oxford, an announcement which was received with enthusiasm by the members, who retain a lively recollection of the success of the last meeting there. The new president is Brig.-Gen. Harold Hartley, and the chairman for I926 Mr. E. J. Holmyard (Clifton College)

\section{University and Educational Intelligence.}

Provisional announcements are now available of a number of free public lectures and short courses by eminent men of science and other scholars, to be given at various colleges of the University of London. Lectures at King's College include three by Prof. A. S. Eddington on the constitution and evolution of the stars, commencing February 22; two by Prof. R. Ruggles Gates on vegetation on the Amazon, commencing February ig; and five by Dr. F. A. P. Aveling on the human will, commencing January I8. At University College, Prof. W. H. Lang is to deliver three lectures on the morphology of the Vascular Cryptogams, commencing March r, at 5.I 5 P.M. ; Dr. C. M. Ariens Kappers, four on the evolution of the nervous system, commencing March 9; Mr. M. H. Krishna, eight on Indian archæology and anthropology, commencing January I 8; Miss M. A. Murray, two on Egyptian architecture and primitive cults in ancient Egypt, commencing January 26 ; Dr. R. W. Lunt, six on the chemistry of ionisation by collision, commencing February I ; Dr. E. G. Richardson, three on the acoustics of buildings, commencing January I9; and Dr. Geoffrey Martin, one lecture on the theory of fine grinding, on February I 2 , at 5 P.M. Lectures at the London School of Economics include one by Dr. B. Malinowski on the aims of social anthropology, on February 18 , at 5 P.M. Except where otherwise stated, the lectures begin at 5.30 P.M.

ALL universities in Ecuador were closed by a Government decree last August. Commenting on this event, the secretary to the United States Legation, Quito, remarks in an article published in the November issue of School Life, that for many years past the degrees of doctor of law and doctor of medicine have been too easy of attainment. To graduate in one of these faculties had come to be looked upon as the best badge of " respectability," and the country is flooded with doctors and lawyers, most of whom are unable to earn a living at their profession, and many of whom are but poorly equipped for it. Similar drastic methods of restricting the recruitment for the legal profession have been adopted in Bolivia, where, however, those who have actually begun their professional courses of study are to be permitted to complete them, after which the law faculties are to be closed down. The editor of School Life asks whether it is not time to apply some restriction to the present scale of output of lawyers in the United States, where students of law are more than twice as numerous as students of medicine. Only 46 of the I6o law schools require for the law degree so much as five years of study after the completion of the secondary school course, and only one-fifth of the whole number of law students were in those 46 schools. The other four-fifths were in schools which conferred the degree for four years of study at most. It is suggested that the levelling-up process that has in recent years been applied to medical studies should be now applied to the study of law.

NO. 2933, VOL. II7] 